\title{
Characterization of Congo red binding in Streptococcus gordonii
}

\author{
Eun Jeong Kim ${ }^{1}$ and Si Young Lee ${ }^{2 \star}$
}

${ }^{1}$ Master's Student, Department of Microbiology and Immunology, College of Dentistry, Gangneung-Wonju National University, Gangneung, Republic of Korea ${ }^{2}$ Professor, Department of Microbiology and Immunology, College of Dentistry, Research Institute of Oral Science, Gangneung-Wonju National University, Gangneung, Republic of Korea

Iron is essential for bacterial growth. The ability to use heme compounds to derive iron in pathogenic bacteria has been reported. In some pathogenic bacteria, studies indicated that hemin binding is related to their Congo red binding abilities. In this study, we investigated the Congo red binding of Streptococcus gordonii, an oral streptococcus, to characterize the association between Congo red and hemin binding. Bacteria and Congo red were mixed and incubated. After centrifugation, the optical density of the supernatant was measured, and the amount of Congo red bound to bacteria was determined using a Congo red standard curve. Adhesion competition analysis between hemin and Congo red in bacteria was also conducted by the pre-binding of $S$. gordonii to hemin and then analyzing Congo red binding. The ability of $S$. gordonii to bind Congo red was increased depending on added bacteria and Congo red quantities. Inhibition of the Congo red binding ability to $S$. gordonii was dependent on pre-bound hemin levels. These data suggested that $S$. gordonii bound Congo red and may contain Congo red binding sites. Competitive analyses also indicated that Congo red and hemin binding in $S$. gordonii may be related.

Key Words: Congo red; Hemin; Ligand binding; Streptococcus gordonii

(ㄷ) This is an open-access article distributed under the terms of the Creative Commons Attribution Non-Commercial License (http://creativecommons.org/licenses/by-nc/4.0) which permits unrestricted noncommercial use, distribution, and reproduction in any medium, provided the original work is properly cited.

\section{Introduction}

Iron is an essential nutrient for the growth of bacteria, and iron is needed for various biochemical and physiological responses of bacteria [1-3]. Oral streptococci that reside in human oral cavity are gram-positive bacteria and play an important role in plaque formation [4]. Some of them cause dental caries and infective endocarditis [5,6]. Streptococcus mutans, also known as the causative bacteria of dental caries, require iron to grow [7]. Therefore, the growth of oral streptococci can be attributed to the ability of bacteria to acquire iron.

Currently, there are three known mechanisms for iron accumulation in bacteria. One is the mechanism by which siderophores present in bacteria act. The siderophore binds to iron to form a ferric siderophore complex, and ferric siderophore binds to a complex present in bacteria. Through this, the bacteria obtain iron [8]. The second mechanism is the use of host iron binding proteins (transferrin, lactoferrin, etc.) $[9,10]$. Some bacteria have low-iron-inducible outer membrane proteins capable of binding to the human iron binding protein, transferrin or lactoferrin, and are used

Received July 29, 2021; Revised August 30, 2021; Accepted September 6, 2021

*Corresponding author: Si Young Lee, Department of Microbiology and Immunology, College of Dentistry, Research Institute of Oral Science, Gangneung-Wonju National University, 7, Jukheon-gil, Gangneung 25457, Republic of Korea.

Tel: +82-33-640-2455, Fax: +82-33-642-6410, E-mail: siyoung@gwnu.ac.kr

Copyright $\odot$ 2021, Oral Biology Research Institute 
to obtain iron through human iron binding proteins $[9,10]$. The third is the mechanism of using heme compounds. It is a mechanism to obtain iron by using hemin binding protein of bacteria that can bind with heme or heme compounds $[11,12]$. Heme compounds can act as an iron source for bacterial growth [13]. Heme compounds can provide a sufficient supply of iron for bacterial growth, even at low concentrations $(<10 \mu \mathrm{M})$ [14].

Several previous studies report that the hemin binding ability of bacteria is closely related to the Congo red binding of bacteria $[13,15-18]$. According to Surgalla and Beesley [19], strains binding to hemin in Yersinia pestis could bind to Congo red, but strains not bound with hemin could not bind to Congo red. In addition, studies on oral spirochetes (Treponema denticola, Treponema vincentii, Treponema socranskii) have also reported that hemin binding of bacteria is associated with Congo red binding [13]. And according to studies on Shigella flexineri, the ability of bacteria to bind to Congo red can be inhibited by hemin and protoporphyrin IX [15,17]. Daskaleros and Payne [15] analyzed Congo red binding of bacteria after hemin and pre-binding $S$. flexineri. They found that hemin and Congo red could bind to the same or closely related sites.

Congo red was reported as one of the identification markers used to distinguish the toxicity and harmlessness of certain bacteria [20]. For example, in vitro experiment on $S$. flexineri showed that the ability to bind Congo red and heme compounds was associated with virulence [20]. In addition, strains bound to Congo red in S. flexneri were toxic, and strains that did not bind to Congo red were found to be harmless in various systems [20].

In this study, the binding of Congo red was analyzed in oral streptococcus, Streptococcus gordonii, one of the early colonizing bacteria in dental plaque formation.

\section{Materials and Methods}

\section{Bacterial strain and culture}

S. gordonii DL1 was cultured on a Todd-Hewitt agar plate (Bectron Dickinson Biosciences, Franklin Lake, NJ, USA) for 1 day at $37^{\circ} \mathrm{C}$ in a $\mathrm{CO}_{2}$ incubator containing $5 \% \mathrm{CO}_{2}$, transferred to a Todd-Hewitt liquid medium and incubated for
18 hours.

\section{Congo red binding assay}

S. gordonii was cultured for 18 hours, and the bacterial pellet was harvested by centrifugation $\left(12,000 \times \mathrm{g}, 4^{\circ} \mathrm{C}\right.$, 10 minutes). Bacteria were washed twice with phosphate buffered saline (PBS) and resuspended in PBS to $\mathrm{OD}_{660}=1.5$ $\left(1 \times 10^{10}\right.$ cells $\left./ \mathrm{mL}\right)$. One $\mathrm{ml}$ of bacterial suspension was incubated with $0.5 \mathrm{~mL}$ of Congo red (Sigma-Aldrich, Saint Louis, MO, USA) (final concentration $30 \mu \mathrm{g} / \mathrm{mL}$ ) for $30 \mathrm{~min}$ utes in a $37^{\circ} \mathrm{C}$ water bath. The optical density (OD) of the supernatant was then analyzed by a spectrophotometer at $488 \mathrm{~nm}$ [21,22], after centrifugation $\left(12,000 \times \mathrm{g}, 4^{\circ} \mathrm{C}\right.$, 10 minutes). The concentration of Congo red present in the supernatant was calculated from the standard curve of Congo red. The amount of Congo red bound to bacteria was calculated by subtracting the amount of Congo red that was left after the reaction from the amount of Congo red initially added [21,22]. Experiments were carried out at various bacterial concentrations $\left(0-20 \times 10^{9}\right.$ cells $\left./ \mathrm{mL}\right)$ to determine if Congo red binding to $S$. gordonii depends on the amount of bacteria. In addition, the experiment was carried out with several concentrations of Congo red (final concentration 0-40 $\mu \mathrm{g} / \mathrm{mL}$ ) to see if Congo red binding of $S$. gordonii was dependent on the concentration of Congo red added.

\section{Competition analysis of hemin and Congo red}

After binding of $S$. gordonii DL1 to hemin, the Congo red binding was analyzed and the relationship between the hemin binding and Congo red binding of the bacteria was confirmed. First, $1 \mathrm{~mL}$ of bacterial suspension $\left(1 \times 10^{10}\right.$ cells $/ \mathrm{ml}$ ) and $0.5 \mathrm{~mL}$ of hemin (final concentration 0-30 $\mu \mathrm{g}$ / $\mathrm{mL}$ ) were incubated in a $37^{\circ} \mathrm{C}$ water bath for 30 minutes. Thereafter, the bacterial pellet obtained by centrifugation $\left(12,000 \times \mathrm{g}, 4^{\circ} \mathrm{C}, 10\right.$ minutes) was washed twice with PBS and resuspended in $1 \mathrm{~mL}$ of PBS. This was incubated with $0.5 \mathrm{~mL}$ Congo red (final concentration $30 \mu \mathrm{g} / \mathrm{mL}$ ) in a $37^{\circ} \mathrm{C}$ water bath for 30 minutes. After centrifugation $\left(12,000 \times \mathrm{g}, 4^{\circ} \mathrm{C}, 10\right.$ minutes), the OD value of the supernatant was measured with a spectrophotometer at 488 
$\mathrm{nm}[21]$.

\section{Statistics analysis}

Statistical significance was determined using a twosample Student t-test. The Student t-test was run through the Software Package for Social Sciences (SPSS version 23; IBM Corp., Armonk, NY, USA) program.

\section{Results}

\section{Congo red binding assay}

To determine whether the Congo red binding capacity of $S$. gordonii is dependent on bacterial concentration, we analyzed several bacterial concentrations. As a result, the bacterial Congo red binding capacity was dependent on the amount of bacteria (Fig. 1). In addition, the experiment was conducted at several Congo red concentrations to determine whether the Congo red binding ability of bacteria was dependent on the amount of Congo red added. Overall, Congo red binding to bacteria was increased dependent on the concentration of added Congo red (Fig. 2). However, when Congo red was added at a high concentration (more than $7.5 \mu \mathrm{g} / \mathrm{mL}$ ), there was no significant difference in the

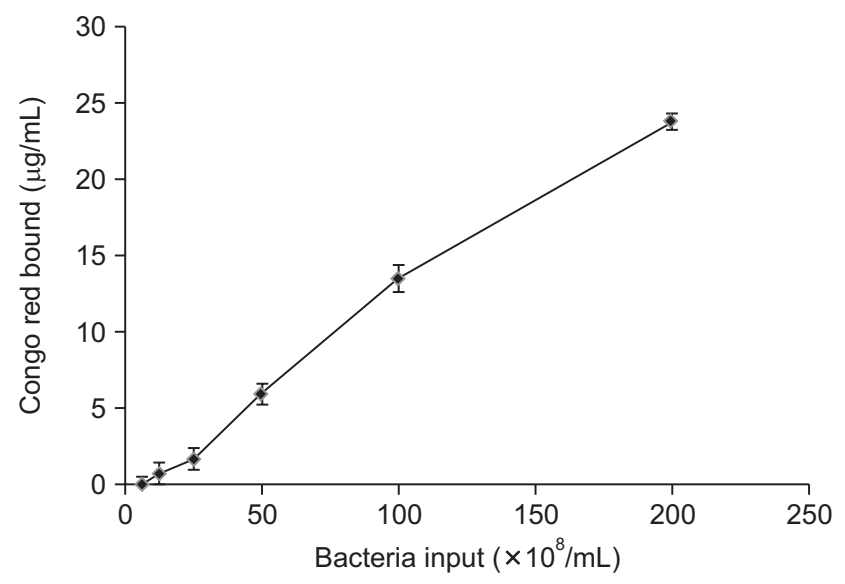

Fig. 1. Effects of bacterial concentration on Congo red binding of $S$. gordonii DL1. S. gordonii $\left(0-200 \times 10^{8}\right.$ cells $\left./ \mathrm{mL}\right)$ were incubated with hemin at $37^{\circ} \mathrm{C}$. After incubation of the mixture for $30 \mathrm{~min}$, bacteria were removed by centrifugation, and the amount of hemin bound was determined by measuring the amount of dye remaining in the supernatant. Values indicate means of duplicate experiment and the error bars indicate standard deviations of the mean. amount of Congo red bound to bacteria even when the concentration of added Congo red was increased

\section{Competition analysis of hemin and Congo red}

To determine the association between hemin binding and Congo red binding, Congo red binding of bacteria was analyzed after hemin prebinding of $S$. gordonii. The results showed that Congo red binding to $S$. gordonii was inhibited by about $23.1 \%$ and $27 \%$, respectively, when hemin $1 \mu \mathrm{g} /$ $\mathrm{mL}$ and $30 \mu \mathrm{g} / \mathrm{mL}$ were pretreated. As the concentration of added hemin increased, the ability to inhibit Congo red binding increased, but there was no significant difference (Fig. 3).

\section{Discussion}

Congo red binds structurally to receptors capable of recognizing this substance, and Congo red binding can be inhibited by structurally very similar compounds [13]. This was suggested by showing that Congo red binding of oral spirochetes is inhibited by hemin and protophorphysin IX in studies on oral spirochetes (T. denticola, $T$. vincentii, $T$.

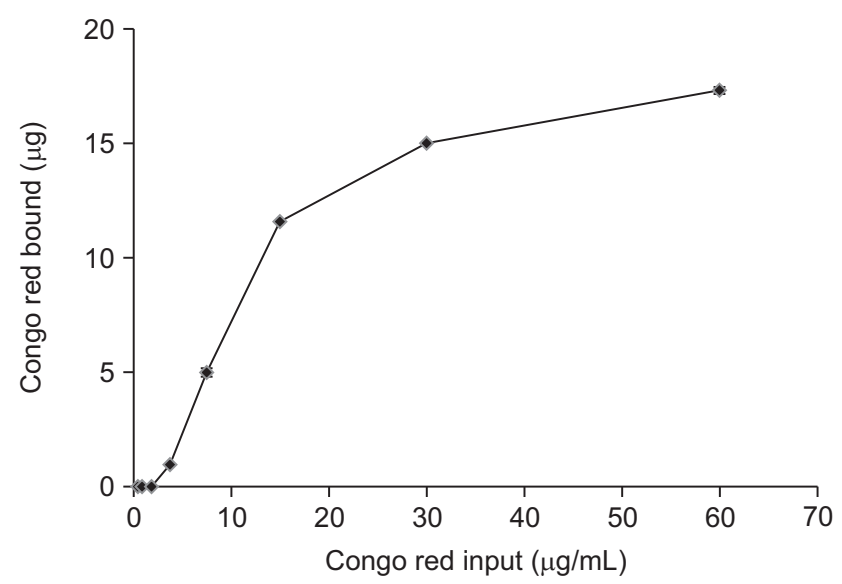

Fig. 2. Effects of Congo red concentration on Congo red binding of $S$. gordonii DL1. The reaction mixture contained $1 \mathrm{~mL}$ of bacterial suspension $\left(\mathrm{OD}_{660}=1.5\right)$ and $0.5 \mathrm{~mL}$ Congo red (final concentration 0 to $30 \mu \mathrm{g} / \mathrm{mL}$ ). After incubation of the mixture at $37^{\circ} \mathrm{C}$ for $30 \mathrm{~min}$, bacteria were removed by centrifugation, and the amount of Congo red bound was determined by measuring the amount of dye remaining in the supernatant. Values indicate means of duplicate experiment and the error bars indicate standard deviations of the mean. Because the standard deviation value is too small, the error bar is obscured by the point. 


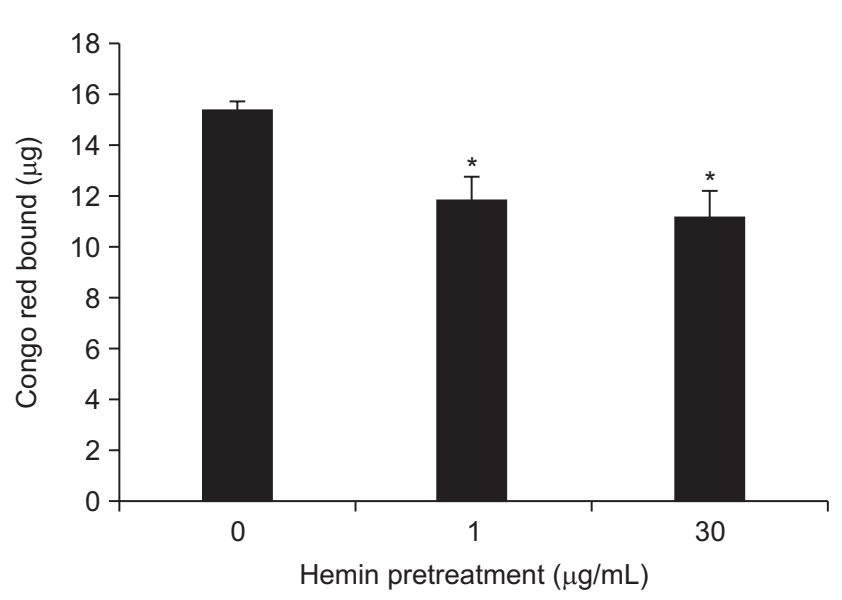

Fig. 3. Competition assays between hemin and Congo red binding to $S$. gordonii. Hemin were allowed to prebind onto the cells, and the excess was removed by washing with PBS, followed by the addition of Congo red (final concentration, $30 \mu \mathrm{g} / \mathrm{mL}$ ). Amount of Congo red bound to bacteria was measured with spectrophotometer. Values indicate means of duplicate experiment and the error bars indicate standard deviations of the mean.

PBS, phosphate buffered saline.

The significant $p$-values $(<0.05)$ are indicated by ${ }^{*}$.

Socranskii) [13].

In this study, the binding of $S$. gordonii to Congo red was analyzed. $S$. gordonii could bind with Congo red, and the amount of Congo red bound to bacteria increased depending on the concentration of added bacteria. In addition, Congo red binding of $S$. gordonii was increased depending on the amount of Congo red added. However, there was no significant difference in the amount of Congo red bound to bacteria even though the amount of Congo red added was increased when high concentration of Congo red was added. This result shows that bacteria can bind only with a certain amount of Congo red. In other words, it suggests that bacteria may have a certain number of Congo red binding sites.

Studies on the association between hemin and Congo red binding have been conducted in several bacteria. Daskaleros and Payne [15] showed that Congo red binding of $S$. flexneri was inhibited by more than $30 \%$ when $S$. flexneri pre-binds with the hemin before binding to Congo red. According to a study by Kay et al. [16], the Congo red binding of bacteria can only be weakly inhibited by structurally similar substances. They showed that when Aeromonas salmonicida was pre-bound with hemin $(30 \mu \mathrm{g} / \mathrm{mL})$, the Congo red binding of bacteria was inhibited by more than $40 \%$.
These results suggest that hemin and Congo red are likely to bind to the same or related sites of bacteria. In this study, it was confirmed that the Congo red binding of $S$. gordonii was inhibited by about $27 \%$ when pre-binding with hemin $(30 \mu \mathrm{g} / \mathrm{mL}$ ) before binding of $S$. gordonii with Congo red. This inhibition rate was similar to previous studies $[15,16]$. When bacteria were pre-bound with hemin, the Congo red binding of $S$. gordonii was inhibited, but the bacteria still showed binding to Congo red. Previous study [15] has assumed two reasons for the above results. One is that Congo red and hemin are structurally very similar, but not identical, so that Congo red can additionally bind to the receptors of hemin-bound bacteria. The other is that Congo red can bind to other site of the bacterium other than the common binding site to which both compounds bind. Although not yet been accurately disclosed, bound hemin might be separated and Congo red may be bound to the hemin separated site since the binding strength of hemin is weak.

Overall, $S$. gordonii has the ability to bind with Congo red, and the Congo red binding capacity of $S$. gordonii is dependent on the concentration of added bacteria and the concentration of Congo red. In addition, the Congo red binding capacity in $S$. gordonii was confirmed to be related to hemin binding. However, we do not know for certain whether the two compounds interact and whether the binding sites of the two compounds in $S$. gordonii are identical. Therefore, in order to more accurately confirm the association between the Congo red binding and the hemin binding of bacteria, identification of binding proteins of two compounds and gene analysis of binding proteins are additionally required.

\section{Conflicts of Interest}

The authors declare that they have no competing interests.

\section{ORCID}

\author{
Eun Jeong Kim \\ https://orcid.org/0000-0001-7380-7698 \\ Si Young Lee \\ https://orcid.org/0000-0001-8826-1413
}




\section{References}

1. Griffiths E. Iron and bacterial virulence--a brief overview. Biol Met 1991;4:7-13. doi: 10.1007/BF01135551.

2. Litwin CM, Calderwood SB. Role of iron in regulation of virulence genes. Clin Microbiol Rev 1993;6:137-149. doi: 10.1128/CMR.6.2.137.

3. Weinberg ED. Iron and infection. Microbiol Rev 1978;42:45-66. doi: 10.1128/mr.42.1.45-66.1978.

4. Baddour LM, Christensen GD, Lowrance JH, Simpson WA. Pathogenesis of experimental endocarditis. Rev Infect Dis 1989;11:452-463. doi: 10.1093/clinids/11.3.452.

5. Roberts RB, Krieger AG, Schiller NL, Gross KC. Viridans streptococcal endocarditis: the role of various species, including pyridoxal-dependent streptococci. Rev Infect Dis 1979;1:955-966. doi: 10.1093/clinids/1.6.955.

6. Bochud PY, Calandra T, Francioli P. Bacteremia due to viridans streptococci in neutropenic patients: a review. Am J Med 1994;97:256-264. doi: 10.1016/0002-9343(94)900094.

7. Arnold RR, Russell JE, Champion WJ, Brewer M, Gauthier JJ. Bactericidal activity of human lactoferrin: differentiation from the stasis of iron deprivation. Infect Immun 1982;35:792-799. doi: 10.1128/iai.35.3.792-799.1982.

8. Moeck GS, Coulton JW. TonB-dependent iron acquisition: mechanisms of siderophore-mediated active transport. Mol Microbiol 1998;28:675-681. doi: 10.1046/j.13652958.1998.00817.x.

9. Pettersson A, Poolman JT, van der Ley P, Tommassen J. Response of Neisseria meningitidis to iron limitation. Antonie Van Leeuwenhoek 1997;71:129-136. doi: 10.1023/ a:1000179301748.

10. Schryvers AB, Stojiljkovic I. Iron acquisition systems in the pathogenic Neisseria. Mol Microbiol 1999;32:1117-1123. doi: 10.1046/j.1365-2958.1999.01411.x.

11. Pidcock KA, Wooten JA, Daley BA, Stull TL. Iron acquisition by Haemophilus influenzae. Infect Immun 1988;56:721725. doi: 10.1128/iai.56.4.721-725.1988.

12. Wooldridge KG, Williams PH. Iron uptake mechanisms of pathogenic bacteria. FEMS Microbiol Rev 1993;12:325348. doi: 10.1111/j.1574-6976.1993.tb00026.x.

13. Scott D, Siboo IR, Chan EC, Klitorinos A, Siboo R. Binding of hemin and congo red by oral hemolytic spirochetes. Oral Microbiol Immunol 1993;8:245-250. doi: 10.1111/j.1399302x.1993.tb00568.x.

14. Zakaria-Meehan Z, Massad G, Simpson LM, Travis JC, Oliver JD. Ability of Vibrio vulnificus to obtain iron from hemoglobin-haptoglobin complexes. Infect Immun 1988;56:275-277. doi: 10.1128/iai.56.1.275-277.1988.

15. Daskaleros PA, Payne SM. Congo red binding phenotype is associated with hemin binding and increased infectivity of Shigella flexneri in the HeLa cell model. Infect Immun 1987;55:1393-1398. doi: 10.1128/iai.55.6.1393-1398. 1987.

16. Kay WW, Phipps BM, Ishiguro EE, Trust TJ. Porphyrin binding by the surface array virulence protein of Aeromonas salmonicida. J Bacteriol 1985;164:1332-1336. doi: 10.1128/jb.164.3.1332-1336.1985.

17. Stugard CE, Daskaleros PA, Payne SM. A 101-kilodalton heme-binding protein associated with congo red binding and virulence of Shigella flexneri and enteroinvasive Escherichia coli strains. Infect Immun 1989;57:3534-3539. doi: 10.1128/iai.57.11.3534-3539.1989.

18. Smalley JW, Birss AJ, McKee AS, Marsh PD. Congo red binding by Porphyromonas gingivalis is mediated by a 66 $\mathrm{kDa}$ outer-membrane protein. Microbiology (Reading) 1995;141(Pt 1):205-211. doi: 10.1099/00221287-141-1205.

19. Surgalla MJ, Beesley ED. Congo red-agar plating medium for detecting pigmentation in Pasteurella pestis. Appl Microbiol 1969;18:834-837. doi: 10.1128/am.18.5.834-837. 1969.

20. Qadri F, Hossain SA, Ciznár I, Haider K, Ljungh A, Wadstrom T, Sack DA. Congo red binding and salt aggregation as indicators of virulence in Shigella species. J Clin Microbiol 1988;26:1343-1348. doi: 10.1128/jcm.26.7.13431348.1988.

21. Genco CA, Odusanya BM, Brown G. Binding and accumulation of hemin in Porphyromonas gingivalis are induced by hemin. Infect Immun 1994;62:2885-2892. doi: 10.1128/ iai.62.7.2885-2892.1994.

22. Deneer HG, Potter AA. Effect of iron restriction on the outer membrane proteins of Actinobacillus (Haemophilus) pleuropneumoniae. Infect Immun 1989;57:798-804. doi: 10.1128/iai.57.3.798-804.1989. 